\title{
PENDIDIKAN KARAKTER PEDULI LINGKUNGAN BERBASIS ADIWIYATA PADA MATA PELAJARAN FIQIH DI MTsN TAMBAKBERAS JOMBANG
}

\author{
Mukani (SMA Negeri 1 Jombang Jawa Timur) \\ Teto Sumarsono (STIT al Urwatul Wutsqo Bulurejo Jombang)
}

\begin{abstract}
Abstrak:
Setiap individu memiliki peran dengan lingkungan sekitarnya dan dapat menciptakan perubahan, terutama tentang kebersihan lingkungan. Kepedulian terhadap lingkungan bisa dilakukan dari lingkup terkecil, yaitu keluarga, sekolah dan madrasah. Artikel ini membahas pembelajaran mata pelajaran fiqih berbasis program adiwiyata yang dilaksanakan di MTsN Tambakberas Jombang dengan pendekatan kualitatif. Berdasarkan hasil penelitian disimpulkan bahwa karakter peserta didik MTsN Tambakberas terhadap kepedulian lingkungan terintegrasi dengan baik melalui pelajaran fiqih dan mata pelajaran lainnya. Sehingga pada mata pelajaran apapun peserta didik akan tetap diingatkan dan dimotivasi untuk selalu peduli dan cinta kepada lingkungannya. Hal ini disebabkan oleh dua usaha, yaitu pembiasaan dan partisipasi. Implementasi pembelajaran fiqih dalam pembentukan karakter peduli lingkungan dilakukan dengan berbagai cara, diantaranya melalui pemberian materi yang terintegrasi dengan mata pelajaran dan juga praktik di lapangan.
\end{abstract}

Kata Kunci: Peduli lingkungan; Adiwiyata; Fiqih. 


\begin{abstract}
:
Everyone has environmental role to create changes, especially in creating cleanliness. Environmental concerns may begin from the smallest scopes, such as family and school or madrasah. This article deals with Islamic jurisprudence learning with concerns of Adiwiyata achievement in MTsN Tambakberas Jombang. This study is using qualitative approach and is conducted at di MTsN Tambakberas Jombang. The result shows that students' attitudes toward environmental issues is satisfying through integration of the issues in Islamic jurisprudence class and other classes. Therefore, in any classes, students are always motivated to love and responsible with their environment. This is a result of two efforts, habitual development and participation. Islamic jurisprudence class contributes in the character building of environmental concerns, either through integrating the concerns into the teaching materials and practice in the fields.
\end{abstract}

\title{
Keywords: Environmental Concerns; Adiwiyata; Islamic Jurisprudence.
}

\section{A. Pendahuluan}

Adiwiyata, menurut Rismawati Tri, memiliki pengertian sebagai tempat yang baik dan ideal, karena dapat diperoleh segala ilmu pengetahuan dan berbagai norma serta etika yang menjadi dasar manusia menuju terciptanya kesejahteraan hidup dan menuju cita-cita pembangunan berkelanjutan. ${ }^{1}$ Adiwiyata dicanangkan untuk mendorong dan membentuk sekolah-sekolah di Indonesia agar mampu melaksanakan upaya pemerintah menuju pelestarian lingkungan dan pembangunan berkelanjutan bagi kepentingan generasi sekarang maupun yang akan datang. Penelitian yang dilakukan menyimpulkan bahwa sekolah banyak melakukan penghijauan dan menjaga kebersihan sekolah meskipun Adiwiyata masih belum diresmikan.

Mirza Desfandi, menulis bahwa mengembangkan masyarakat berkarakter peduli lingkungan dimungkinkan dapat efektif melalui pendidikan lingkungan di sekolah. Program Adiwiyata dilaksanakan guna mewujudkan warga sekolah yang bertanggung jawab dalam upaya perlindungan dan pengelolaan lingkungan hidup melalui tata kelola sekolah yang baik untuk mendukung pembangunan berkelanjutan. Program Adiwiyata menggabungkan pembelajaran dan tindakan, sehingga memberikan metode yang efektif untuk

\footnotetext{
1Rismawati Tri, "Efektivitas Program Adiwiyata Sebagai Upaya Penanaman Rasa Cinta Lingkungan di SMP Negeri 3 Malang," Jurnal Pendidikan Kewarganegaraan, Vol. 2 No. 1 (2013).
}

Jurnal Pendidikan Agama Islam (Journal of Islamic Education Studies)

Volume 5 Nomor 2 (2017)

ISSN(p) 2089-1946\& ISSN(e) 2527-4511

Hal. 182 - 200 
mengubah perilaku. Warga sekolah selanjutnya diharapkan mampu menjadi contoh dan menularkan karakter peduli lingkungan kepada masyarakat. ${ }^{2}$

Hal senada diuraikan Ellen Landriany, yang mengkomparasikan upayaupaya dalam mengatasi hambatan program Adiwiyata pada SMAN 8 dan SMN 10 Kota Malang. Hasil penelitian menunjukkan bahwa kebijakan lingkungan hidup di sekolah telah dituangkan dalam surat keputusan dan terintegrasi dalam masing-masing mata pelajaran. Namun masih dijumpai berbagai situasi permasalahan yang menghambat pelaksanaan Adiwiyata, seperti satuan tugas yang tidak tepat waktu dan ada sekelompok siswa yang masih belum sadar dalam memahami konsep sekolah berwawasan lingkungan hidup, masalah pendanaan dan dukungan masyarakat serta instansi lain yang masih rendah. Sekolah telah melakukan langkah-langkah strategi guna mengatasi hambatan. ${ }^{3}$

Amirul Mukminin al-Anwari, menjelaskan bahwa sekolah, sebagai unit pendidikan untuk mengoptimalkan potensi siswa, telah seharusnya secara kontinyu menanamkan karakter kepada siswa. Hal ini dapat dilihat di SDN Tanjungsekar 1 Malang dan SDN Tulungrejo 4 Batu. Kedua sekolah telah sampai pada level Adiwiyata Mandiri. Artikel Al-Anwari mengkomparasikan berbagai strategi dari kedua sekolah dalam mengatasi berbagai permasalahan dalam melaksanakan program Adiwiyata. ${ }^{4}$

Trikinasih Handayani, mengkaji lebih detail tentang praksis dari Pendidikan Lingkungan Hidup (PLH) dan pembudayaan nilai kebangsaan pada siswa sekolah dasar Adiwiyata mandiri di Yogyakarta secara terintegrasi. Hasil penelitian menunjukkan bahwa proses pembelajaran PLH di objek penelitian telah secara terintegrasi dengan mata pelajaran Ilmu Pengetahuan Alam, (IPA), Ilmu Pengetahuan Sosial (IPS), agama serta seni budaya dan keterampilan (SBK). Secara formal sekolah menempatkan PLH terintegrasi pada mata pelajaran tersebut, tetapi kegiatan-kegiatan yang berkaitan dengan lingkungan secara eksklusif dipisahkan menjadi kegiatan tersendiri. ${ }^{5}$

Yanti Dwi Rahmah, menulis bahwa sekolah objek kajian lolos dalam seleksi tahap kota, namun tahap selanjutnya mengalami ketidakberhasilan dalam

${ }^{2}$ Mirza Desfandi, "Mewujudkan Masyarakat Berkarakter Peduli Lingkungan Melalui Program Adiwiyata," Jurnal Sosio Didaktika, Vol. 2 No. 1 (2015), 31-37.

${ }^{3}$ Ellen Landriany, "Implementasi Kebijakan Adiwiyata Dalam Upaya Mewujudkan Pendidikan Lingkungan Hidup di SMA Kota Malang," Jurnal Kebijakan dan Pengembangan Pendidikan, Vol. 2 No. 1 (Januari 2014), 82-88.

${ }^{4}$ Amirul Mukminin Al-Anwari, "Strategi Pembentukan Karakter Peduli Lingkungan di Sekolah Adiwiyata Mandiri," Jurnal Ta'dib, Vol. 19 No. 2 (November 2014), 227-252.

5Trikinasih Handayani, "Pembudayaan Nilai Kebangsaan Siswa Pada Pendidikan Lingkungan Hidup Sekolah Dasar Adiwiyata Mandiri," Jurnal Pembangunan Pendidikan, Vol. 3 No. 1 (Juni 2015), 95-105. 
mencapai penghargaan Adiwiyata. Hasil penelitian menunjukkan bahwa terdapat empat program yang diterapkan, yaitu komposter, takakura, pembibitan dan program 4R. Program tersebut diterapkan berdasarkan komponen kebijakan berwawasan lingkungan, pelaksanaan kurikulum berbasis lingkungan, kegiatan lingkungan berbasis partisipatif dan pengelolaan sarana pendukung ramah lingkungan. Penerapan program tersebut terdapat faktor pendukung internal, yaitu SDM yang mumpuni dan adanya visi, misi, fungsi serta pengelolaan anggaran yang baik. ${ }^{6}$

Efektivitas program Adiwiyata di sekolah telah dengan baik diuraikan Badarudin. ${ }^{7}$ Hasil-hasil dari pengumpulan data di lapangan menunjukkan terdapat perbedaan efektivitas peningkatan keterampilan berpikir kreatif antara siswa yang memperoleh pembelajaran dengan model PjBL dan siswa yang memperoleh pembelajaran dengan model non-PjBL. Terdapat perbedaan efektivitas peningkatan sikap peduli lingkungan antara siswa yang memperoleh pembelajaran dengan model PjBL dan siswa yang memperoleh pembelajaran dengan model non-PjBL.

Berdasarkan pendapat di atas, karakter manusia, terutama peduli lingkungan, diperlukan bangsa ini untuk mencegah kerusakan lingkungan yang belakangan menjadi permasalahan bangsa Indonesia. Jika manusia peduli terhadap lingkungan, maka kerusakan terhadap lingkungan akan berkurang. Kepedulian terhadap lingkungan bisa dilakukan dari lingkup terkecil, yaitu lingkungan keluarga, sekolah dan madrasah, sehingga peserta didik diajarkan agar peduli terhadap lingkungan yang ada di sekitarnya, dengan membersihkan ruangan, halaman, banyak menanam pohon di sekitar rumah, madrasah dan mengolah sampah organik maupun anorganik. ${ }^{8}$

Penanaman karakter peduli lingkungan dalam dunia pendidikan bertujuan agar peserta didik memiliki pengetahuan dan kesadaran bahwa setiap individu memiliki peran dengan lingkungan di sekitarnya dan dapat menciptakan perubahan, terutama tentang kebersihan lingkungan. Dalam pembentukan karakter peduli lingkungan tersebut dapat dikembangkan melalui beberapa program yang dibentuk secara khusus untuk melatih dan membiasakan peserta didik berperilaku baik terhadap lingkungan sekitarnya. Salah satunya dalam pembentukan karakter peduli lingkungan adalah melalui pembelajaran fiqih.

\footnotetext{
${ }^{6} Y a n t i$ Dwi Rahmah, "Implementasi Program Sekolah Adiwiyata; Studi Pada SDN Manukan Lor III/540 Kota Surabaya," Jurnal Administrasi Publik, Vol. 2 No. 4 (2014).

${ }^{7}$ Badarudin, "Efektivitas Project Based Learning Terhadap Keterampilan Berpikir Kreatif dan Sikap Peduli Lingkungan Siswa Sekolah Dasar," Jurnal Universitas Pendidikan Indonesia, Vol. 483-497.

${ }^{8}$ Sri Utami Rahmawati, Meningkatkan Karakter Peduli Lingkungan Melalui Sekolah Berbudaya Lingkungan Hidup (Bandung: Universitas Pendidikan Indonesia, 2014).
}

Jurnal Pendidikan Agama Islam (Journal of Islamic Education Studies)

Volume 5 Nomor 2 (2017)

ISSN(p) 2089-1946\& ISSN(e) 2527-4511

Hal. 184 - 200 
Fiqih merupakan ilmu yang mengkaji hukum (norma) shariah yang menyangkut tingkah laku manusia yang bersumber dari dalil-dalil partikuler. ${ }^{9}$ Secara prinsip, manusia harus memiliki perilaku peduli lingkungan yang tinggi, karena manusia memiliki hubungan sosiologis maupun biologis secara langsung dengan lingkungan hidup tempat berada, sejak lahir sampai meninggal dunia nanti. Namun, dilihat dari sisi manusia, lingkungan merupakan sesuatu yang bersifat pasif, sedangkan yang aktif adalah manusia. Sehingga kualitas lingkungan sangat bergantung pada kualitas manusia, namun manusia sering lupa bahwa lingkungan yang berkualitas buruk akan berpengaruh pada kualitas kehidupannya.

Artikel ini akan membahas pembelajaran mata pelajaran fiqih berbasis program adiwiyata yang dilaksanakan di MTsN Tambakberas Jombang. Mata pelajaran ini berorientasi kepada pendidikan karakter yang diharapkan mampu menumbuhkan kepedulian terhadap kelestarian lingkungan hidup. Artikel ini juga akan mendeskripsikan faktor-faktor pendukung dan penghambat dalam pelaksanaan program tersebut di atas.

\section{B. Karakter Peduli Lingkungan}

Berdasarkan observasi yang telah dilakukan, peserta didik di MTsN Tambakberas pada dasarnya telah memiliki karakter peduli terhadap lingkungan, seperti selalu menjaga kebersihan, masuk kelas sepatu dilepas, memakai air wudlu secukupnya dan tidak berlebihan, sehingga dalil-dalil dari alQur'an atau hadith mengenai kepedulian lingkungan telah banyak diaplikasikan, baik melalui materi pelajaran maupun melalui praktek kehidupan sehari hari.

Nilai-nilai pendidikan karakter dan budaya cinta lingkungan yang ada di MTsN Tambakberas adalah seluruh anggota sekolah, baik guru, siswa maupun tenaga kependidikan harus menjadi pribadi yang memiliki rasa kepedulian yang tinggi. Kondisi riil karakter siswa peduli lingkungan di MTsN Tambakberas berdasarkan hasil wawancara dengan Kepala MTsN Tambakberas, Moh. Syuaib adalah sebagai berikut:

"Alhamdulillah siswa di MTsN ini telah menerapkan karakter peduli lingkungan, terutama hasil dari integrasi implementasi pembelalajaran fiqih, yang mana di materi fiqih semua kitab dimulai dari bab thoharoh (sesuci). Yang mana kaitanya fiqih dengan peduli lingkungan yaitu siswa ketika berwudlu menggunakan air tidak belebih-lebihan, ketika masuk kelas kaki dibasuh agar bersih dari kotoran atau najis dan bekas dari air berwudlu dialirkan ke titik lokasi perkampungan guna pengairan lahan pertanian penduduk. Kkalau di MTsN Tambakberas sini, karakter peduli lingkungan tidak hanya dari hasil integrasi pembelajaran fiqih saja, akan tetapi banyak pelajaran integrasi yang lain, seperti IPA, IPS Matematika

\footnotetext{
${ }^{9}$ Salman Madkur, al-Fiqih al-Islam (ttp: Maktabah Abdullah Wahbah, 1995), 44.
} 
dan lain-lain, karena di sini sekolahnya berbudaya lingkungan, sehingga di materi diajarkan tentang karakter peduli lingkungan begitu juga pada tindakan agar anak terbiasa untuk mencintai lingkungan, baik di sekolah maupun di rumah dan di manapun dia berada."10

Ketika ditanyakan waktu mulai MTsN Tambakberas menerapkan karakter peduli lingkungan, Moh. Syuaib menjelaskan bahwa telah sejak dulu madrasah ini menerapkan karakter peduli lingkungan, bahkan sejak MTsN Tambakberas masih dipimpin oleh KH. Syamsul Huda, KH. Al-Fatich Abdurahim dan sampai sekarang. Pada tahun 2012 MTsN Tambakberas memperoleh penghargaan juara satu Adiwiyata tingkat kabupaten dan yang paling besar yaitu mendapatkan penghargan Adiwiyata Nasional pada tahun 2014 dan sekarang menuju Adiwiyata mandiri.

Hal senada diungkapkan oleh Luluk Syarifah, wakil kepala bidang kurikulum MTsN Tambakberas berikut ini:

“Karakter siswa peduli lingkungan di sini juga telah berjalan apalagi di MTsN Tambakberas telah mendapatkan penghargaan sekolah Adiwiyata. Dalam progam ini juga tidak terlepas dari kegiatan belajar mengajar terutama pelajaran fiqih yang mana di situ pertama kali yang dibahas adalah masalah kebersihan, semisal membuang sampah pada tempatnya, membasuh kaki ketika masuk kelas dan diharapkan siswa selalu melakukan dawamul wudlu ketika akan memulai pelajaran. Semua itu merupakan wujud dari Islam juga, tidak sedikit dalil mengenai kebersihan lingkungan, kebersihan diri dan lain-lain. Ragam bentuk karakter peduli lingkungan di MTsN Tambakberas tidak hanya cinta akan kebersihan, di sini juga ada kegiatan penghijauan, daur ulang sampah dan lainlain."11

Pada saat wawancara dengan Manasihul Anam, selaku guru mata pelajaran Fiqih di MTsN Tambakberas, dijelaskan bahwa kondisi karakter siswa di MTsN Tambakberas sebagai berikut:

" $Y a$, alhamdulillah siswa menerapkan karakter peduli lingkungan kaitanya dengan air, yaitu ketika berwudlu tidak belebih-lebihan, sistemnya menggunakan kran dan bak mandi, air bekas wudlu yang sekian banyak siswa yang memakai air tersebut dialirkan ke perkampungan atau menyiram tanaman, ketika dalam membersihkan najis dan kotoran dibersihkan dulu dengan tisu atau yang lain tiga kali kemudian diusap dengan kain basah dan air sesucukupnya. Ditambahkan juga pelajaran fiqih itu paling mudah di dunia, karena manusia sejak lahir pun telah diajari tentang fiqh, manusia setiap hari juga tidak terlepas dari fiqih yang mana fiqih adalah mengajarkan tentang syariat Islam."12

10Moh. Syuaib, Wawancara, Jombang, 9 Maret 2017.

${ }^{11}$ Luluk Syarifah, Wawancara, jombang, 10 Maret 2017.

12Manasihul Anam, Wawancara, Jombang, 9 Maret 2017.

Jurnal Pendidikan Agama Islam (Journal of Islamic Education Studies)

Volume 5 Nomor 2 (2017)

ISSN(p) 2089-1946\& ISSN(e) 2527-4511

Hal. 186 - 200 
Mukhlas Ubaidillah, guru pembimbing adiwiyata, pada kesempatan lain, menambahkan juga bahwa kondisi karakter siswa akan peduli lingkungan yang tidak jauh berbeda dari yang disampaikan oleh informan lainnya, yaitu:

"Siswa hemat air ketika berwudlu, hemat energi, pembiasaan kelas dan halaman bersih, membuang sampah sesuai tempatnya, baik sampah organik maupun organik. Semuanya itu telah berjalan, tetapi masih butuh proses agar menjadi lebih baik lagi dengan cara sesama teman peduli atau saling mengingatkan, di manapun berada, akan tetap berlaku peduli lingkungan, aturan dalam pembentukan karakter, diadakanya perangkat dalam mengaktualisasikan kelompok kerja, seperti patroli air atau mengamati aliran air, patroli lingkungan bersih dari sampah."13

Fakta ini tidak hanya diakui oleh para guru. Namun para peserta didik juga mengakui, sebagaimana penuturan Syaifudin, siswa di MTsN Tambakberas kelas IX B menjelaskan tentang kondisi karakter siswa peduli lingkungan berikut ini:

"Mengenai kondisi karakter siswa peduli lingkungan di sini sebagian sangat memperhatikan hal tersebut, contohnya membuat jadwal piket kelas, hemat air ketika berwudlu, menjaga kesucian kelas, membuang sampah pada tempatnya dan lain-lain. Tidak hanya siswa saja, akan tetapi sebagian guru juga melakukan hal tersebut."14

Abdul Aziz, siswa kelas IX-B lainnya, juga menambahkan bahwa siswa di madrasah ini mengadakan Sabtu bersih, seperti menyapu halaman, kelas, mushala, kamar mandi dan WC. Aziz juga berharap karakter agar yang seperti ini terus dikembangkan oleh teman-teman semuanya karena dirinya sangat senang jika di madrasah yang tercinta ini bersih dan ramah lingkungan, sehingga kegiatan belajar mengajar menjadi menyenangkan. ${ }^{15}$ Sedangkan pada jam selanjutnya penulis melakukan observasi dikelas IX-I putri, karena di kelas ini jauh lebih nyaman dari kelas putra. Rosyidah, dalam wawancara bersama di kelas, menyampaikan fakta-fakta sebagai berikut:

"Siswa di sini alhamdulillah perilaku akan cinta lingkungan lumayan besar, seperti memakai air secukupnya, masuk kelas tidak pakai sepatu, mengikuti progam pokja, akan tetapi sebagian masih ada yang kurang peduli hal tersebut seperti membuang sampah sembarangan."16

Berdasarkan hasil wawancara di atas, dapat disimpulkan bahwa kondisi riil karakter peduli lingkungan siswa MTsN Tambakberas telah mengaplikasikan

\footnotetext{
${ }^{13}$ Muhlas Ubaidillah, Wawancara, Jombang, 17 Maret 2017.

14 Syaifudin, Wawancara, Jombang, 11 Maret 2017.

${ }^{15}$ Abdul Aziz, Wawancara, Jombang, 11 Maret 2017.

16 Wahidatu Rosyidah, Wawancara, Jombang, 11 Maret 2017.
} 
hal-hal yang menjadi tuntunan syariat Islam, yaitu menjaga dan melestarikan lingkungan dengan menjaga kebersihan, adanya kelompok kerja (Pokja), menggunakan air secukupnya ketika berwudlu, kebiasaan membuang sampah sesuai dengan tempatnya, baik sampah organik maupun organik, dan adanya tiga tim lingkungan, yaitu tim patroli irigasi, tim kader kebersihan dan tim kader lingkungan.

\section{Pembelajaran Fiqih Peduli Lingkungan}

Hubungan pendidikan peduli lingkungan hidup dengan agama sangat erat, yaitu dengan penumbuhan karakter cinta lingkungan yang didasari dengan dalil sehingga dapat memantapkan peserta didik dalam melakukan upaya peningkatan karakter peduli lingkungan yang berkonsep keaktifan dan istiqamah siswa dalam kelakukannya. Dalam hal ini kepala MTsN Tambakberas menjelaskan bahwa pembentukan karakter peduli lingkungan melalui pembelajaran, khususnya mata pelajaran fiqih, sangat besar karena pelajaran ini banyak tuntunan syariat Islam yang berhubungan manusia sehari-hari, mulai

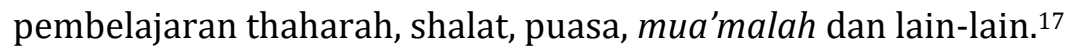

Luluk Syarifah, wakil kepala bidang kurikulum, dalam kesempatan yang lain juga mengungkapkan sebagai berikut:

"Bahwasanya sebagai waka kurikulum peranan saya dalam membentuk karakter siswa peduli lingkungan yaitu mengoptimalkan setiap mata pelajaran diintegrasikan dengan pelajaran peduli lingkungan, tidak terkecuali pelajaran fiqih diisi pada pelajaran pertama yang dibahas yaitu tentang thoharoh atau kebersihan."18

Menurut Manasihul Anam, guru mata pelajaran fiqih di MTsN Tambakberas, implementasi pembelajaran fiqih dalam pembentukan karakter siswa peduli lingkungan telah terintegrasikan dengan baik, sehingga tidak ada pemisah antara pelajaran fiqih dengan peduli ligkungan. Hal ini ditegaskan dalam hasil wawancara berikut ini:

"Seperti yang kita ketahui semua bahwasanya siswa di MTsN ini mayoritas bertempat tinggal di pondok, sehingga tidak hanya diajar disekolahan saja, akan tetapi dipondok akan lebih mendalam mengenai kitab-kitab fiqih yang membahas tentang kehidupan manusia. Yang terpenting yaitu sebagai pendidik selain mengajarkan pelajaran di kelas juga memasukkan karakter peduli lingkungan, saya juga mendidik mereka dengan yang dicontohkan rasul, yaitu sebagai suri tauladan atau contoh bagi mereka. Jadi selain jadi guru yang memberikan teori pada peserta didik tentang pentingnya peduli terhadap lingkungan, saya juga mencontohkan kepada mereka sehingga mereka bukan disuruh, tapi diajak. Banyak contohnya pak, misalnya menghemat air ketika berwudlu, karena dalam Islam ada anjuran untuk tidak berlebihan menggunakan

17 Moch. Syuaib, Wawancara, Jombang, 9 Maret 2017.

${ }^{18}$ Luluk Syarifah, Wawancara, Jombang, 16 Maret 2017.

Jurnal Pendidikan Agama Islam (Journal of Islamic Education Studies)

Volume 5 Nomor 2 (2017)

ISSN(p) 2089-1946\& ISSN(e) 2527-4511

Hal. 188 - 200 
air ketika berwudlu, kami sebagai guru juga memberi contoh untuk tidak berlebihan dalam menggunakan air saat wudlu, sehingga mereka tau bahwa kami sebagai guru tidak hanya memberikan teori saja, tapi juga penerapan dalam kehidupan sehari-hari. Contoh lain misalnya ketika ada sampah di kelas atau di halaman, kita sebagai pendidik jangan malu untuk memungutnya, justru malah ketika kita sebagai pendidik yang memungutnya, peserta didik itu akan merasa malu atau bahkan merasa tersindir, guru saja mau memungut sampah yang ada di kelas, sedangkan mereka yang peserta didik malah mengotorinya. Dan diharapkan mereka juga termotivasi untuk hidup bersih, jadi kita memberi contoh."19

Hal senada juga disampaikan oleh Habibullah, salah satu pendidik lainnya di MTsN Tambakberas, sebagaimana hasil wawancara berikut ini:

"Dalam mengimplementasikan pelajaran menjadi sebuah karakter yang peduli dan cinta lingkungan, khususnya pelajaran fiqih ini variatif sesuai dengan karakter materi atau anak, dalam pembelajaran yang kami ajarkan kepada siswa yaitu $4 \mathrm{M}$, yaitu mendengar, melihat, membaca dam mempraktekan). Di samping itu dalam pembentukan karakter anak menjadi shaleh di MTsN Tambakberas siswa diharuskan dawam al wudlu, istiqamah jamaáh shalat Dluha dan Dluhur. Dalam menjadi karakter siswa peduli lingkungan siswa diajarkan praktek langsung dengan cara membuang sampah pada tempatnya dengan 3 jenis, kertas, daun dan plastik, mengajak siswa becocok tanam, memelihara satwa dan lain-lain." 20

Irham Lathif, tenaga kependidikan di MTsN Tambakberas, juga menjelaskan bahwa cinta terhadap lingkungan adalah tujuan dari Pendidikan Agama Islam. Hal ini dapat dipahami dari hasil wawancara berikut ini:

"Sebenarnya peduli lingkungan adalah tugas kita semua, baik siswa guru dan masyarakat umumnya, karena inilah perwujudan dari keimanan kita, dalam agama Islam berapa banyak dalil yang mengingatkan kita agar selalu menjaga lingkungan. Di sinilah tanggung jawab kita untuk memenuhinya, tetapi semua itu tidak semudah yang kita bayangkan, kita semua butuh proses menjadikan karakter siswa yang peduli lingkungan dengan cara pembiasaan dalam kehidupan sehari-hari."21

Hal senada juga disampaikan oleh guru pembimbing adiwiyata di MTsN Tambakberas, sebagaimana hasil wawancara berikut ini:

“Di MTsN Tambakberas ini kami sebagai pendidik mengajarkan untuk memiliki rasa peduli tehadap lingkungan sebenarnya tidak hanya pembelajaran fiqih saja yang berintegrasi dengan wawasan karakter peduli lingkungan, hampir semua mata pelajaran telah terintegrasi dengan karakter peduli lingkungan dan telah

\footnotetext{
${ }^{19}$ Manasihul Anam, Wawancara, Jombang, 11 April 2017.

${ }^{20}$ Habibullah, Wawancara, Jombang, 14 Maret 2017.

${ }^{21}$ Irham Lathif, Wawancara, Jombang, 15 Maret 2017.
} 
masuk pada kurikulum dan indikator-indikator pada beberapa materi. Meskipun telah disediakan jam pelajaran khusus pendidikan karakter peduli lingkungan. Hal ini dilakukan agar peserta didik terbiasa untuk tidak membeda-bedakan antara mata pelajaran umum dengan karakter peduli lingkungan, terutama pelajaran agama yang erat kaitannya dengan pendidikan karakter. Jadi pak, pada mata pelajaran apapun mereka akan tetap terbiasa untuk mencerminkan sikap peduli dan cinta terhadap lingkungannya."22

Saat melakukan observasi dan wawancara di kelas IX-B, diperoleh hasil sebagai berikut:

“Dalam mengimplementasikan pelajaran fiqih dalam pembentukan karakter peduli lingkungan yaitu dengan cara mempraktekanya secara langsung menghemat air, tidak memakai sepatu ke dalam kelas, membasuh kaki dulu. Berkat ilmu fiqih yang kami dapat sehingga kami mengetahui hukum dan syariat islam secara kaffah. ${ }^{23}$

Hal senada juga diutarakan oleh Wahidatu Rosyidah, salah satu siswa kelas IX-I putri, sebagaimana hasil wawancara berikut ini:

"Kami semua langsung mempraktekanya pak, karena pelajaran fiqih itu ilmu yang membahas hukum dan syariat Islam setiap hari, jadi kami semua di samping mencintai lingkungan sekitar dengan cara membuat jadwal piket, membuang sampah sesuai tempatnya, memberihkan ruang kelas, halaman/taman sekolah, kamar mandi/WC, kami juga diajarkan 5 S 1 D (Salam, senyum, sapa, shodaqoh, sholat dan dawamul wudlu), tapi awalnya itu semua tidak mudah, awalnya kami dulu dipaksa lama kelamaan menjadi kebiasaan dan kami semua terus selamanya akan selalu peduli lingkungan di manapun kami berada. Selain itu juga dilakukan pembiasaan shalat jamaah Dluha dan Dluhur, selain untuk menambah kekompakan warga madrasah serta dijadikan kebiasaan siswa, baik ketika dalam dan di luar madrasah, namun tidak semua warga madrasah melaksanakan budaya tersebut, masih ada beberapa anak yang membuang sampah tanpa memilahnya, tetapi guru tidak bosan mengingatkan dan menasehati."24

Berdasarkan hasil-hasil wawancara di atas, dapat disimpulkan bahwa pembentukan karakter siswa peduli lingkungan di MTsN Tambakberas melalui pembelajaran fiqih telah terintegrasi dengan baik, bahkan hampir semua mata pelajaran. Sehingga pada mata pelajaran apapun peserta didik akan tetap diingatkan dan dimotivasi untuk selalu peduli dan cinta kepada lingkungannya. Hal ini disebabkan oleh dua hal, yaitu pembiasaan dan partisipatif.

Selain melalui kurikulum dan silabus yang telah disusun, implementasi pembelajaran fiqih dalm pembentukan karakter peduli lingkungan di sekolah

22Manasihul Anam, Wawancara, Jombang, 18 Maret 2017.

${ }^{23}$ Ahmad Wisnu, Wawancara, Jombang, 11 Maret 2017.

${ }^{24}$ Wahidatu Rosyidah, Wawancara, Jombang, 11 Maret 2017.

Jurnal Pendidikan Agama Islam (Journal of Islamic Education Studies)

Volume 5 Nomor 2 (2017)

ISSN(p) 2089-1946\& ISSN(e) 2527-4511

Hal. 190 - 200 
adiwiyata MTsN Tambakberas ini adalah melalui pembiasaan. Sebagaimana hasil wawancara dengan kepala sekolah sebagai berikut:

"Iya pak, kita membiasakan siswa agar mereka terbiasa untuk menjadi pribadi yang ulet dan produktif melalui kegiatan peduli lingkungan dan rasa tanggung jawab untuk melestarikan lingkungan, baik di sekolah maupun di lingkungan rumah dan masyarakat." 25

Hal ini senada dengan yang disampaikan Muhlas Ubaidillah, guru pembimbing adiwiyata di MTsN Tambakberas. Sebagaimana hasil wawancara berikut ini:

"Iya pak, kita berusaha membiasakan agar peserta didik menjadi pribadi yang partisipatif dan produktif. Hal ini dilakukan melalui penanaman rasa tanggung jawab pada peserta didik untuk menjaga lingkungan dan kelestarian alam."26

Seluruh warga sekolah di MTsN Tambakberas dibiasakan untuk hidup sehat dan peduli dengan lingkungan, salah satunya dengan aktif berpartisipasi dalam menjaga dan melestarikan lingkungan sekitarnya. Selain itu peserta didik juga dilatih menjadi generasi produktif, yaitu mampu menciptakan atau membuat karya dari benda-benda yang telah tidak terpakai yang nantinya akan dijual, sehingga secara tidak langsung peserta didik juga dilatih untuk berbisnis. Diharapkan siswa akan membawa kebiasaan mulia tersebut dimanapun mereka berada.

Hal tersebut didukung pula oleh pendapat Nur Bintang, salah seorang peserta didik di MTsN Tambakberas, sebagai berikut:

"Di MTsN Tambakberas ini memang sekolah peduli lingkungan pak, hampir semua mata pelajaran juga selalu dimasuki karakter peduli lingkungan, termasuk pelajaran Fiqih, biasanya Pak Anam memberikan tugas kepada kami untuk mencari artikel atau tulisan, dalil 'aqli maupun naqli yang berkaitan dengan anjuran untuk peduli terhadap lingkungan dan contoh-contoh yang menunjukkan sikap peduli terhadap karakter peduli lingkungan, baik yang bersumber dari buku maupun dari internet. Pada materi thaharah, biasanya Pak Anam mengaitkan dengan hemat air ketika bersuci, bukan berarti tidak bersih, tapi memakai air secukupnya, selain itu kita sering sekali diberi motivasi untuk selalu meningkatkan kepekaan pada lingkungan, jadi kami terbiasa untuk melakukan kegiatan peduli lingkungan pada semua mata pelajaran terutama pada pelajaran fiqih." 27

Berdasarkan hasil wawancara di atas dapat ditarik kesimpulan bahwa selain pada saat kegiatan pembelajaran berlangsung, siswa juga dilatih agar

\footnotetext{
25Moh. Syuaib, Wawancara, Jombang, 10 Maret 2017.

${ }^{26}$ Muhlas Ubaidillah, Wawancara, Jombang, 18 Maret 2017.

27Tazkiya Nur Cahyani, Wawancara, Jombang, 11 Maret 2017.
} 
terbiasa menjadi pribadi yang peduli dan cinta kepada lingkungan. Sehingga diharapkan di manapun mereka berada, mereka tetap mencerminkan sikap peduli terhadap lingkungannya.

Implementasi pembelajaran fiqih dalam pembentukan karakter siswa peduli lingkungan di MTsN Tambakberas, selain melalui kurikulum pembelajaran berbasis lingkungan dan pembiasaan, juga bersifat partisipatif dan berkelanjutan. Hal ini diperoleh dari hasil wawancara dengan guru pendidikan lingkungan hidup sebagai berikut:

"Di MTsN Tambakberas memiliki konsep partisipatif dan berkelanjutan pak. Adapun yang dimaksud partisipatif adalah bahwa semua komunitas sekolah terlibat dalam menejemen sekolah, baik itu perencanaan, pelaksanaan ataupun evaluasi sesuai peran dan tanggung jawab masing-masing. Sementara yang saya maksud dengan berkelanjutan adalah semua kegiatan harus dilakukan secara terencana dan komprehensif. Dan disini ada beberapa pengembangan dari pendidikan lingkungan hidup, antara lain pengembangan kebijakan sekolah peduli dan berbudaya lingkungan, pengembangan budaya peduli lingkungan, pengembangan kurikulum berbasis lingkungan dan pengembangan berbasis partisipatif, seperti yang telah saya jelaskan sebelumnya, dan pengembangan dan pengelolaan sarana pendukung. Jadi semua unsur terlibat dalam kaitannya dengan peningkatan karakter peduli lingkungan., ${ }^{28}$

Berdasarkan hasil wawancara di atas, dapat disimpulkan bahwa implementasi pembelajaran fiqih dalam pembentukan karakter siswa peduli lingkungan di sekolah adiwiyata MTsN Tambakberas, yaitu dengan terlibatnya semua unsur yang ada di sekolah, baik itu kepala sekolah, tenaga kependidikan maupun peserta didik untuk menunjukkan sikap peduli terhadap lingkungan melalui ajaran agama atau dalil-dalil yang ada di dalam al-Qur'an yang disusun dalam silabus dan kurikulum pembelajaran berbasis lingkungan serta melalui pembiasaan.

Sedangkan dari hasil observasi peneliti berkaitan dengan implementasi pembelajaran fiqih dalam pembentukan karakter siswa peduli lingkungan di sekolah adiwiyata MTsN menunjukkan bahwa seluruh warga sekolah turut bertanggung jawab dalam peningkatan karakter peduli lingkungan, misalnya setiap kelas bertanggung jawab atas kebersihan kelas dengan jadwal piket, tidak memakai sepatu ke dalam kelas, memakai air secukupnya ketika berwudhu, sebelum jam belajar ada waktu untuk merawat, menyiram tanaman dan lain sebagainya.

Pembentukan karakter peduli lingkungan adalah penanaman melalui pelajaran agama, baik tersirat maupun tersurat dan melalui penugasan agar peserta didik mencari sendiri dalil-dalil dan contoh perilaku Nabi Muhammad Saw yang menunjukkan sikap karakter peduli lingkungan. Hal ini dapat

28Muhlas Ubaidillah, Wawancara, Jombang, 18 Maret 2017.

Jurnal Pendidikan Agama Islam (Journal of Islamic Education Studies)

Volume 5 Nomor 2 (2017)

ISSN(p) 2089-1946\& ISSN(e) 2527-4511

Hal. 192 - 200 
dibuktikan dengan beberapa kegiatan peserta didik, dalam pembenahan yang berbasis lingkungan, antara lain membuat kelompok kerja (pokja), selalu merawat aneka jenis tanaman, memelihara satwa, tidak ada sampah yang berserakan sebagai wujud kebersihan sebagian dari iman, peserta didik tidak pernah berlebihan ketika menggunakan air dan selalu memilih makanan sehat. ${ }^{29}$

\title{
D. Faktor Pendukung dan Penghambat
}

Pelaksanaan progam dalam pembentukan karakter siswa peduli lingkungan di MTsN Tambakberas tidak mudah, di samping ada penghambatnya juga ada pendukungnya. Setelah melakukan observasi maupun wawancara, ditemukan fakta bahwa banyak faktor pendukung dan penghambat, seperti yang disampaikan oleh Moh. Syuaib, kepala MTsN Tambakberas, sebagaiman berikut ini:

\begin{abstract}
"Pertama, lokasi madrasah yang cukup luas. Kedua, tersedianya fasilitas/sarana pendukung pelaksanaan kegiatan serta adanya dukungan dari warga madrasah, peran aktif siswa melalui kegiatan piket harian di kelas, membuang sampah pada tempatnya dan adanya progam sekolah adiwiyata. Progam ini banyak memberikan dampak positif bagi MTsN Tambakberas seperti terciptanya sekolah yang berwawasan lingkungan, terbentuknya karakter siswa yang peduli alam sekitar sesuai dengan visi misi madrasah, yakni terwujudnya generasi yang sholeh, cerdas, berkarakter dan berwawasan lingkungan. Karena adanya adiwiyata ini juga memperkecil bumi mengalami kerusakan, alam semakin terjaga keseimbanganya. Dengan adiwiyata juga melahirkan generasi muda yang berkarakter dan ramah terhadap lingkungan. Sedangkan faktor penghambatnya; pertama, adanya pengaruh negatif dari luar. Kedua, siswa yang bebeda-beda dari latar-belakang keluarga dan pengetahuan yang berbeda. Ketiga, kurangnya pemahaman dan kesadaran siswa untuk menerapkan sikap cinta terhadap lingkungan."30
\end{abstract}

Hal senada juga diungkapkan Manasihul Anam, guru Pembina adiwiyata di MTsN Tambakberas, bahwa faktor pendukung dalam pembentukan karakter siswa peduli lingkungan adalah fasilitas/sarana prasarana pendukung, materi keagamaan yang lebih, pembiasaan siswa dalam kegiatan peduli lingkungan dan adanya progam adiwiyata. Sedangkan untuk faktor penghambatnya kurang adanya kesadaran dari siswa memahami konsep peduli lingkungan, terutama masalah kebersihan, kurang adanya kepedulian sesama guru maupun siswa, berbagai latar belakang yang berbeda, pemahaman tentang materi yang berbeda, sangat banyaknya jumlah siswa, karena semua itu akan berdampak negatif terhadap perkembngan karakter siswa peduli lingkungan. ${ }^{31}$

\footnotetext{
${ }^{29}$ Observasi penulis di MTsN Tambakberas Jombang pada 20 Maret 2017.

30Moh. Syuaib, Wawancara, Jombang, 10 Maret 2017.

${ }^{31}$ Manasihul Anam, Wawancara, Jombang, 18 Maret 2017.
} 
Hal senada juga disampaikan oleh Muhlas Ubaidillah, guru di MTsN Tambakberas, yang terangkum dalam hasil wawancara berikut ini:

"Kalau pendukungnya ya warga telah banyak mengerti tentang kaedah fiqih, adanya progam adiwiyata yang mana dengan adanya progam tersebut semua warga sekolah lebih giat lagi, fasilitas yang ramah lingkungan, kerjasama dan pembinaan dengan BPLH dan materi PLH sehingga tahun ke tahun MTsN Tambakberas menggapai prestasi yang luar biasa. Pada tahun 2012 mendapatkan penghargaan sekolah adiwiyata tingkat kabupaten dan provinsi, tahun 2013 mendapatkan Adiwiyata Nasional. Setelah mendapatkan penghargaan Adiwiyata Nasional MTsN Tambakberas sedang menuju Adiwiyata Mandiri dan syarat untuk menjadi Madrasah Adiwiyata Mandiri adalah membina minimal 10 madrasah/sekolah. Soal faktor penghambatnya, ya siswa masih kurang memahami konsep fiqih, khususnya masalah kebersihan dan kesucian, budaya lingkungan yang kurang memahami, sulit mengubah image untuk hidup bersih dan sehat."32

Menurut Habibullah, guru di MTsN Tambakberas yang lain, juga menjelaskan tentang faktor pendukung dan penghambat dalam implementasi program ini. Hal tersebut bisa diketahui dari hasil wawancara berikut ini:

"Jadi kebanyakan siswa MTsN Tambakberas ini berasal dari pesantren, kurang sadar akan pentingnya kebersihan lingkungan, padahal materi telah banyak mengenai dalil-dali tentang peduli lingkungan. Sedangkan faktor pendukungnya adalah sarana prasarananya hampir memenuhi standar kopetensi yang ingin dicapai madrasah, adanya progam Adiwiyata."33

Tidak jauh berbeda yang dikemukakan oleh Tazkiya Nur Cahyani, salah satu siswa kelas IX-I puteri, dalam observasi dan wawancara mengenai faktor pendukung dan penghambat karakter siswa peduli lingkungan. Hal ini tercantum dalam hasil wawancara berikut ini:

"Kalau masalah faktor pendukung itu menurut aku telah hampir lengkap dalam melaksanakan kegiatan peduli lingkungan, akan tetapi tidak semuanya siswa bisa memanfaatkan sarana tersebut, adanya progam Adiwiyata sehinggan muncul berbagai macam kelompok kerja (pokja), seperti kelompok kerja kebun, pokja daur ulang kertas, pokja bank sampah dan lain-lain. Sedangkan dalam penghambatnya yaitu kurang kesadaran berbeda latar belakang siswa dan sebagian ada yang malas pentingnya menjaga lingkungan madrasah." ${ }^{34}$

Berdasarkan penjelasan dan hasil wawancara di atas, dapat diketahui bahwa faktor pendukung dalam pembentukan karakter peduli lingkungan adalah sarana dan prasarana pendukung pelaksanaan kegiatan, dukungan dari semua warga sekolah, adanya progam Adiwiyata dan pendidikan lingkungan hidup

32Ibid.

${ }^{33}$ Habibullah, Wawancara, Jombang, 22 Maret 2017.

34Tazkiya Nur Cahyani, Wawancara, Jombang, 11 Maret 2017.

Jurnal Pendidikan Agama Islam (Journal of Islamic Education Studies)

Volume 5 Nomor 2 (2017)

ISSN(p) 2089-1946\& ISSN(e) 2527-4511

Hal. 194 - 200 
(PLH). Sedangkan penghambatnya adalah kurang adanya kesadaran dalam memahami ilmu agama khususnya ilmu fiqih, siswa dari latar belakang yang berbeda dan adanya dampak negatif dari luar.

\section{E. Membangun Karakter Peduli Lingkungan pada Anak Didik}

Dipahami bahwa karakter identik dengan akhlak, sehingga karakter merupakan nilai-nilai perilaku manusia yang universal dan meliputi seluruh aktivitas manusia, baik dalam berhubungan dengan Tuhannya, dengan dirinya, dengan sesama manusia, maupun dengan lingkungannya, yang terwujud dalam pikiran, sikap, perasaan, perkataan dan perbuatan berdasarkan norma-norma agama, hukum, tata karma, budaya dan adat istiadat. ${ }^{35}$ Pendidikan karakter harus menjadi gerakan nasional yang menjadikan sekolah (institusi pendidikan) sebagai agen untuk membangun karakter peserta didik melalui pembelajaran dan pemodelan. Melalui pendidikan karakter, sekolah harus berpretensi untuk membawa peserta didik memiliki nilai-nilai karakter mulia, seperti hormat dan peduli pada orang lain, tanggung jawab, jujur, memiliki integritas dan disiplin.

Pendidikan karakter tidak hanya mengajarkan mana yang benar dan mana yang salah kepada anak, tetapi lebih dari itu pendidikan karakter menanamkan kebiasaan (habituation) tentang yang baik sehingga peserta didik paham, mampu merasakan dan mau melakukan yang baik. Pendidikan karakter membawa misi yang sama dengan pendidikan akhlak atau pendidikan moral.

Berdasarkan pengertian karakter di atas, dapat disimpulkan kaitannya dengan karakter peserta didik yang peduli lingkungan. Pendidikan berkarakter peduli lingkungan dapat dipahami sebagai usaha yang dilakukan untuk meningkatkan kepedulian terhadap lingkungan, baik itu dalam melestarikan, menjaga ataupun mencegahnya dari kerusakan lingkungan yang akan terjadi dengan merujuk dari indikator peduli lingkungan di MTsN Tambakberas. ${ }^{36}$

Indikator madrasah meliputi pembiasaan memelihara lingkungan madrasah, tersedianya tempat pembuangan sampah dan tempat cuci tangan dan kaki, menyediakan kamar mandi atau WC dan air bersih, pembiasan hemat air dan energi, membangun saluran air limbah dengan baik, melakukan pembiasaan memisahkan jenis sampah organik dan anorganik, penugasan pembuatan kompos dari sampah, menyediakan alat kebersihan, membuat tandon penyimpanan air dan memprogamkan cinta bersih lingkungan. Indikator kelas berupa memelihara dan membersihkan lingkungan kelas, tersedianya tempat

\footnotetext{
35Sutarjo Adisusilo, Pembelajaran Nilai Karakter (Jakarta: Rajawali Pers, 2012), 77.

36 Nilai-nilai karakter dimaksudkan agar siswa memiliki sikap dan tindakan yang selalu berupaya mencegah kerusakan pada lingkungan alam sekitarnya dan mengembangkan upaya untuk memperbaiki kerusakan yang telah terjadi.
} 
sampah di depan kelas, memasang stiker atau tulisan perintah menjaga kebersihan kelas.

Hasil penelitian yang dilakukan oleh peneliti menunjukkan bahwa pada dasarnya para peserta didik di MTsN Tambakberas telah memiliki nilai karakter peduli lingkungan yang baik dan kini digalakkan lebih semangat lagi dengan menjadi anak yang dilatih dan dibiasakan untuk merawat lingkungan madrasah, mulai dari kebersihan, penghematan air, merawat tanaman dan lain-lain. Di MTsN juga ditanamkan orang yang berwirausaha, yaitu memanfaatkan sesuatu agar menjadi sesuatu yang benilai, seperti adanya kelompok kerja (pokja) kuliner, pokja daur ulang kertas dan plastik, pokja kedelai, pokja jamur, pokja kompos, pokja kebun dan lain sebagainya.

Karakter peduli lingkungan yang dimiliki oleh peserta didik tersebut diperoleh dari pembiasaan yang tidak mudah, melainkan membutuhkan proses yang lama, akan tetapi pembiasaan tersebut tidak hanya diterapkan untuk peserta didik saja, namun juga berlaku untuk seluruh warga sekolah. Berdasarkan hasil penelitian, baik berupa wawancara, observasi dan dokumentasi dalam penelitian ini, kondisi karakter peserta didik MTsN Tambakberas terkait masalah peduli lingkungan bahwasannya kondisi karakter peduli lingkungan berpusat pada semua warga sekolah, terutama para peserta didik. Hal ini dibuktikan dengan keaktifan, kedisiplinan peserta didik dan semangat peserta didik dalam mengikuti setiap kegiatan yang berhubungan dengan kepedulian terhadap lingkungan. ${ }^{37}$

MTsN Tambakberas saat ini menuju Adiwiyata mandiri setelah lolos adiwiyata nasional. Seluruh warga madrasah bahu-membahu guna mengantarkan meraih penghargaan tersebut. Seiring dengan berjalanya waktu telah banyak sekali perubahan yang terjadi, antara lain di MTsN Tambakberas dulunya sering terjadi genangan air ketika hujan tiba kini dapat teratasi karena adanya biopori dan sumur resapan, volume sampah yang semakin berkurang karena adanya pemilahan sampah sehingga mempermudah pemanfaatanya, bertambahnya keanekaragaman hayati dan satwa dan masih banyak lagi. Budaya-budaya karakter yang sejak dulu ada kini mulai ditekankan kembali, yaitu kebiasaan membuang dan pengelolahan sampah, baik organik maupun anorganik sesuai dengan tempatnya.

Pembelajaran, di satu sisi, adalah proses interaksi peserta didik dengan pendidik dan sumber belajar pada suatu lingkungan belajar. Pembelajaran merupakan bantuan yang diberikan pendidik agar mampu terjadi proses pemerolehan ilmu dan pengetahuan, penguasaan kemahiran dan tabiat serta

\footnotetext{
37 Kepedulian terhadap lingkungan yang dilakukan oleh peserta didik terdapat tiga tim lingkungan, yaitu tim patroli irigasi, tim kader lingkungan dan tim kebersihan. Semua warga ikut dalam kegiatan tersebut.
} 
pembentukan sikap dan kepercayaan kepada peserta didik. Pembelajaran adalah proses untuk membantu peserta didik agar dapat belajar dengan baik.

Pembelajaran Fiqih secara subtansional memiliki kontribusi dalam memberikan motivasi kepada peserta didik untuk mempraktekkan dan menerapkan hukum Islam dalam kehidupan sehari-hari sebagai perwujudan keserasian, keselarasan dan keseimbangan hubungan manusia dengan Allah Swt, dengan diri manusia itu sendiri, sesama manusia, makhluk lainnya ataupun lingkungannya dalam membentuk karakter peduli lingkungan. Pendidik dalam melakukan penerapan dari pembelajaran fiqih dari hasil penelitian dengan berbagai cara, baik melalui materi dan juga praktek langsung. ${ }^{38}$

Itu semua juga tidak terlepas dari muatan kurikulum pembelajaran fiqih yang diintegrasikan dengan pendidikan lingkungan hidup yang ada di MTsN Tambakberas, seperti peserta didik dapat mengkategorikan najis dan tidak, dapat menunjukan jenis-jenis air, dapat memanfaatkan sumber mata air untuk thaharah, menjaga ketersediaan air untuk kebersihan. Pembentukan karakter peserta didik peduli lingkungan di sekolah Adiwiyata MTsN Tambakberas tidak hanya pelajaran fiqih saja, akan tetapi semua pelajaran juga bisa diintegrasikan dengan karakter peduli lingkungan dan yang tidak kalah penting yaitu dengan pelibatan semua unsur yang ada di sekolah, baik itu kepala sekolah, tenaga kependidikan maupun peserta didik untuk menunjukkan sikap peduli terhadap lingkungan melalui ajaran agama atau dalil-dalil yang ada di dalam al-Qur'an yang disusun dalam silabus dan kurikulum pembelajaran berbasis lingkungan serta melalui pembiasaan.

Karakter peduli lingkungan di MTsN Tambakberas, secara prinsip, ada pelajaran khusus yang membahasnya, namun telah ada integrasi ke dalam mata pelajaran, pengembangan diri dan budaya sekolah. Guru dan sekolah perlu mengintegrasikan secara sempurna. Pendidik memiliki peran penting dalam keberhasilan sebuah proses pembelajaran, termasuk guru fiqih. Guru fiqih merupakan seorang guru yang memberikan materi ajaran Islam yang memiliki tugas tidak hanya untuk mentransfer ilmu pengetahuan saja, namun juga untuk membentuk karakter peserta didik untuk berakhlak mulia sebagaimana tujuan diajarkanya pelajaran fiqih. 39

38 Metode praktek dilakukan agar peserta didik senantiasa mengingat bahwa peduli lingkungan tidak hanya bermanfaat di dunia, melainkan tercatat sebagai amal ibadah, seperti yang dikemukakan oleh pendidik MTsN Tambakberas, yaitu kaitannya dengan fiqih peserta didik dalam memakai air tidak berlebihan, memanfaatkan bekas air berwudlu untuk lahan perkampungan, selalu menjaga kesucian kelas dan lain sebagainya.

39 Tujuan pembelajaran fiqih di MTsN Tambakberas adalah mengetahui dan memahami pokok-pokok hukum Islam dalam mengatur ketentuan dan tata cara melaksanakan hubungan manusia dengan Allah Swt, manusia dengan manusia dan manusia dengan lingkungan, termasuk karakter peduli lingkungan sekitar, mengingat lingkungan merupakan 
Setelah melakukan wawancara dengan tenaga pendidik MTsN Tambakberas diketahui bahwa di MTsN Tambakberas telah ada pembentukan karakter peduli lingkungan, yaitu melalui implementasi pelajaran fiqih dan seluruh mata pelajaran yang lain, bahkan ada jam khusus untuk lebih meningkatkan karakter kepedulian terhadap lingkungan, karena di MTsN Tambakberas adalah salah satu madrasah berwawasan lingkungan atau yang biasa disebut Madrasah Adiwiyata.

Pelaksanaan progam yang ditetapkan oleh suatu lembaga adalah suatu keharusan yang dijalani semua warga yang terlibat dalam suatu lembaga tersebut, mengingat di MTsN Tambakberas kini telah memiliki progam sekolah adiwiyata. Hal ini tidak mudah dalam pencapaian tersebut apalagi MTsN Tambakberas menuju sekolah adiwiyata mandiri, maka hal ini perlu adanya saling kerjasama antar warga sekolah yang terlibat di dalamnya. Peneliti dalam melakukan wawancara dan observasi lapangan, di samping banyak faktor pendukung, masih ada juga faktor penghambat dalam pembentukan karakter peduli lingkungan.

Faktor pendukung pelaksanaan program ini adalah lahan madrasah yang cukup luas, sarana dan fasilitas pendukung kegiatan peduli lingkungan, peran aktif peserta didik dan pembiasaan seperti membuat jadwal piket harian serta adanya materi Pendidikan Lingkungan Hidup (PLH) dan progam Adiwiyata. Faktor penghambat dari program ini meliputi banyaknya jumlah peserta didik, kurang adanya kesadaran peserta didik dalam memahami pentingnya karakter menjaga lingkungan, peserta didik berasal dari latar belakang keluarga yang berbeda, latar belakang pendidikan peserta didik sebelumnya sangat variatif, peserta didik masih dalam usia labil sehingga mudah terbawa arus atau pengaruh budaya dan arus informasi global, sehingga peserta didik banyak menyerap hal-hal negatif dari media massa, khusunya internet.

\section{F. Kesimpulan}

Berdasarkan pembahasan dan analisis di atas, dapat disimpulkan bahwa kondisi riil karakter peserta didik MTsN Tambakberas terkait peduli lingkungan pada dasarnya telah memiliki nilai-nilai karakter peduli lingkungan yang baik dan kini digalakkan lebih semangat lagi dengan menjadi anak yang dilatih dan dibiasakan untuk merawat lingkungan madrasah. Implementasi pembelajaran fiqih dalam pembentukan karakter peduli lingkungan di MTsN Tambakberas dilakukan dengan berbagai cara, yaitu melalui materi dan juga praktik langsung, dimana seorang guru menyampaikan materi melalui pembelajaran dan juga memberikan teladan langsung melalui praktik di lapangan. Pembelajaran fiqih yang diajarkan di MTsN Tambakberas diintegrasikan dengan pendidikan

salah satu hal penting yang harus dijaga dan dilestarikan dan sumber daya berharga yang akan diwariskan kepada generasi penerus.

Jurnal Pendidikan Agama Islam (Journal of Islamic Education Studies)

Volume 5 Nomor 2 (2017)

ISSN(p) 2089-1946\& ISSN(e) 2527-4511

Hal. 198 - 200 
lingkungan. Faktor pendukung dan penghambat juga ditemukan dalam pelaksanaan kegiatan peduli lingkungan di MTsN Tambakberas Jombang.

\section{G. Referensi}

Adisusilo, Sutarjo. Pembelajaran Nilai Karakter. Jakarta: Rajawali Pers, 2012.

Anwari (al), Amirul Mukminin. "Strategi Pembentukan Karakter Peduli Lingkungan di Sekolah Adiwiyata Mandiri." Jurnal Ta'dib, Vol. 19 No. 2 (November 2014).

Badarudin. "Efektivitas Project Based Learning Terhadap Keterampilan Berpikir Kreatif dan Sikap Peduli Lingkungan Siswa Sekolah Dasar." Jurnal Universitas Pendidikan Indonesia, Vol. 483-497.

Desfandi, Mirza. “Mewujudkan Masyarakat Berkarakter Peduli Lingkungan Melalui Program Adiwiyata." Jurnal Sosio Didaktika, Vol. 2 No. 1 (2015).

Handayani, Trikinasih. "Pembudayaan Nilai Kebangsaan Siswa Pada Pendidikan Lingkungan Hidup Sekolah Dasar Adiwiyata Mandiri." Jurnal Pembangunan Pendidikan, Vol. 3 No. 1 (Juni 2015).

Landriany, Ellen. "Implementasi Kebijakan Adiwiyata Dalam Upaya Mewujudkan Pendidikan Lingkungan Hidup di SMA Kota Malang." Jurnal Kebijakan dan Pengembangan Pendidikan, Vol. 2 No. 1 (Januari 2014).

Madkur, Salman. al-Fiqih al-Islam. ttp: Maktabah Abdullah Wahbah, 1995.

Rahmah, Yanti Dwi. "Implementasi Program Sekolah Adiwiyata; Studi Pada SDN Manukan Lor III/540 Kota Surabaya." Jurnal Administrasi Publik, Vol. 2 No. 4 (2014).

Rahmawati, Sri Utami. Meningkatkan Karakter Peduli Lingkungan Melalui Sekolah Berbudaya Lingkungan Hidup. Bandung: Universitas Pendidikan Indonesia, 2014.

Tri, Rismawati. "Efektivitas Program Adiwiyata Sebagai Upaya Penanaman Rasa Cinta Lingkungan di SMP Negeri 3 Malang." Jurnal Pendidikan Kewarganegaraan, Vol. 2 No. 1 (2013).

Anam, Manasihul. Wawancara. Jombang, 9 Maret 2017, 18 Maret 2017, 11 April 2017.

Aziz, Abdul. Wawancara. Jombang, 11 Maret 2017. 
Mukani \& Teto Sumarsono

Cahyani, Tazkiya Nur. Wawancara. Jombang, 11 Maret 2017.

Habibullah. Wawancara. Jombang, 14 Maret 2017, 22 Maret 2017.

Lathif, Irham. Wawancara. Jombang, 15 Maret 2017.

Rosyidah, Wahidatu. Wawancara. Jombang, 11 Maret 2017.

Syaifudin. Wawancara. Jombang. 11 Maret 2017.

Syarifah, Luluk. Wawancara. Jombang, 10 Maret 2017, 16 Maret 2017.

Syuaib, Moh. Wawancara. Jombang, 9 Maret 2017, 10 Maret 2017.

Ubaidillah, Muhlas. Wawancara. Jombang, 17 Maret 2017, 18 Maret 2017.

Wisnu, Ahmad. Wawancara. Jombang, 11 Maret 2017.

Jurnal Pendidikan Agama Islam (Journal of Islamic Education Studies)

Volume 5 Nomor 2 (2017)

ISSN(p) 2089-1946\& ISSN(e) 2527-4511

Hal. 200 - 200 